\title{
Designing an Information Technology Curriculum: The Georgia Southern University Experience
}

\author{
Han Reichgelt, Aimao Zhang \& Barbara Price \\ Georgia Southern University, Statesboro, GA 30460, U.S.A.
}

\section{han@gasou.edu aimao@gasou.edu baprice@gasou.edu}

\section{Executive Summary}

The chronic and severe shortage of skilled Information Technology (IT) workers is well documented. At the same time, many regional and national governments have made the provision of information technology services an important element in their economic development strategies. It is against this background that Georgia Southern University established a School of Information Technology in March, 2001, and started a baccalaureate program in Information Technology in August of 2001. Unlike many other baccalaureate programs in Information Technology, the program at Georgia Southern University did not grow out of existing programs in Information Systems or Computer Science, but was designed de novo.

The process that Georgia Southern University used in designing its curriculum included extensive consultations with representatives from companies that were either directly involved in the IT industry or employed large numbers of IT professionals. The result of this consultation was the formulation of a set of skills that industry representatives agreed they would like any entry-level graduate in Information Technology to be able to demonstrate. The curriculum was then designed in such a way that it ensured that successful graduates would indeed possess such skills.

The paper describes the curriculum offered at Georgia Southern University, and shows how the various courses in the curriculum contribute to the graduate's acquisition of the relevant skills. It pays particular attention to the inclusion of so-called second disciplines, a feature that distinguishes Georgia Southern University's curriculum from Information Technology curricula offered elsewhere. Second disciplines are 21 credit hour programs of study that give students an in-depth exposure to an IT application area and were included in response to the complaint made by many IT organizations that they have difficulty recruiting entry-level staff with both a good grounding in IT and in the particular application area of interest to the company in question. We believe that the process that Georgia Southern University used in the design of its IT baccalaureate curriculum in general and the inclusion of second disciplines in it, in particular, will lead to graduates who are more likely to meet the human resource demands of companies with a large IT workforce.

Material published as part of this journal, either on-line or in print, is copyrighted by the publisher of the Journal of Information Technology Education. Permission to make digital or paper copy of part or all of these works for personal or classroom use is granted without fee provided that the copies are not made or distributed for profit or commercial advantage AND that copies 1) bear this notice in full and 2) give the full citation on the first page. It is permissible to abstract these works so long as credit is given. To copy in all other cases or to republish or to post on a server or to redistribute to lists requires specific permission and payment of a fee. Contact Editor@JITE.org to request redistribution permission.
Keywords: Curriculum Design, Information Technology Curricula.

\section{Introduction}

It is well established that there is a severe shortage of skilled Information Technology (IT) workers worldwide. Based on data supplied by the Bureau of Labor Statistics, the Office of Technology Policy concluded that the US alone would create nearly 138,000 new IT related jobs per year through 2006 
(U.S. Department of Commerce, 1998). The Information Technology Association of America (ITAA, 2002) found that, despite the economic downturn, managers hiring IT staff expect that of the roughly 1.15 million positions for IT workers projected for 2002, over 575,000 will remain unfilled. Moreover, the situation is not unique to the United States. Similar skill shortages have been reported in Western Europe and Canada.

At the same time, many national and regional governments see IT as an attractive industry for them to woo. IT-related jobs attract high salaries and most areas of IT, in particular those related to software and services, are not capital intensive and are environmentally friendly. The State of Georgia in the US is one example of a state government trying to establish a large IT sector within the state. Georgia has had considerable success in attracting IT jobs to the Atlanta Metropolitan Area. However, Atlanta is facing many of the environmental difficulties associated with rapid urban growth. Moreover, many Georgians, including those in the political directorate, are concerned about the growing income gap between Atlanta and the remainder of Georgia, often referred to as rural Georgia. There have been concerted attempts to attract IT jobs to rural Georgia as well.

It was against this background that Georgia Southern University, a comprehensive university in Southern Georgia, a predominantly rural area, established a School of Information Technology in March 2001. The primary mission of the School is to provide baccalaureate programs in IT with the aim of preparing students to take on entry-level positions as IT specialists in a variety of organizations.

The proposal that led to the establishment of the School was formulated by a multi-disciplinary task force $^{1}$, which was set up in May 2000. The task force visited a number of schools already offering baccalaureate programs in IT and obtained information from companies with a significant IT workforce (see Appendix A for a list). In August 2000, the task force produced a comprehensive strategic plan for the establishment of a School of Information Technology (Georgia Southern University, 2000). The Board of Regents of the University System of Georgia accepted the proposal in March of 2001, and the School started teaching its initial IT course with an enrollment of 114 students in August of 2001. Currently, Georgia Southern University has 239 IT majors.

Although the School of Information Technology is administratively located within the College of Business Administration, for accreditation purposes, the baccalaureate program in IT is treated as completely separate. In particular, this means that the requirements that are normally imposed on programs offered within a business school by accrediting agencies do not apply to the baccalaureate program in IT. Furthermore, the Board of Regents of the University System of Georgia has approved the establishment of a College of Information Technology, which is slated to come into existence in June of 2003, and the baccalaureate program in IT will at that stage move from the College of Business Administration to the College of Information Technology.

The original proposal that led to the establishment of the School of Information Technology contained many detailed plans, including plans for the construction of a building to house the proposed school and for recruitment of staff and students. It also contained a set of curriculum proposals and the focus on this paper is on these, and specifically on those aspects of the curriculum that distinguish Georgia Southern University's curriculum from the curricula offered elsewhere. We will also discuss the way in which we have brought to reality some of the curriculum proposals in the original plan.

\footnotetext{
${ }^{1}$ The taskforce was chaired by Barbara Price, the then Chair of the Department of Information Systems and Logistics (ISL). Its members were June Alberto (School of Nursing), Max Burns (ISL), Don Fausett (Mathematics and Computer Science), Phyllis Isley (Bureau of Business Research and Economic Development), Bruce McLean (Mathematics and Computer Science), Dallas Rhodes (Geology and Geography), Reed Smith (Communication Arts), David Williams (School of Technology), Susan Williams (ISL) and Dana Chirieac (Graduate Assistant, ISL).
} 


\section{Objectives of the Baccalaureate Program in Information Technology}

The proposal to establish the School of Information Technology was formulated by a task force which was able to visit a number of schools already offering baccalaureate programs in IT, as well as to interact with representatives from firms with large IT workforces. Based on the knowledge gained, the task force formulated a set of objectives or learning outcomes.

Students graduating with a Bachelor of Science in IT will be able to:

1. Identify and define the requirements that must be satisfied to solve organizations' problems or opportunities;

2. Develop IT-based solutions in one or more application areas;

3. Demonstrate independent critical thinking and problem solving skills;

4. Apply rational analytical techniques to the development of IT based solutions;

5. Identify current and emerging technologies and discuss their applicability to today's organizations;

6. Demonstrate expertise in the core technologies that support all IT based applications;

7. Communicate effectively with clients and peers, both orally and in writing;

8. Work effectively in project teams to implement IT based solutions;

9. Use advanced project management methods in complex systems development environments.

The objectives can be classified into three categories. The first class concerns objectives that one would expect in any baccalaureate program in any area of academic endeavor. This class includes the capacity for independent critical thought and problem solving (objective 3 ) and the ability to communicate effectively, both orally and in writing (objective 7). After all, one would expect the holder of any baccalaureate degree to have acquired these skills.

The second set of objectives concerns objectives that the IT curriculum at Georgia Southern University has in common with IT curricula offered elsewhere. These include the ability to identify the user's or organizational requirements for a new information system (objective 1), the ability to identify current and emerging technologies and their applicability to today's organization (objective 5), expertise in core IT technologies (objective 6), the ability to work in project teams to implement IT based solutions (objective 8 ), and the ability to use advanced project management methods (objective 9).

The third class of objectives is unique to the IT curriculum offered at Georgia Southern University. The primary one is objective 2, namely the ability to develop IT solutions in one or more application areas, and the related objective 4, the ability to apply rational analytical techniques in the development of ITbased solutions. Some IT baccalaureate programs give students some exposure to an application area, but typically these application areas are in business. What makes the IT program at Georgia Southern University unique is the fact that students are free to choose application areas outside business. We discuss a number of these other application areas later in the paper.

At this stage, it is noteworthy that the primary reason for the introduction of the final set of objectives came from feedback that the task force received from industry. Industry representatives reported that they found that many of the applicants for IT-related entry-level positions had a solid grounding in technical matters but lacked any exposure in the area of particular interest to the company. If they had any exposure to material outside IT, it tended to be in areas such as finance and management. However, 
many companies were looking for IT specialists who had knowledge relevant to their specific areas of activity. For example, companies like The Southern Company and The Home Depot would obviously prefer their applicants for IT jobs to have a good knowledge of power generation or logistics, as well as of IT itself, whereas ESRI, the manufacturer of ArcInfo, one of the most widely geographical information systems, would prefer their new hires to have more than a passing knowledge of geography and geographical information systems.

\section{Organization of the Program}

The organization of the baccalaureate program in IT at Georgia Southern University follows quite naturally from the sets of objectives described in the previous section. The first set of objectives are general educational objectives and in line with the other baccalaureate programs at Georgia Southern University, and indeed baccalaureate programs offered in other US universities, students are expected to read a number of general education courses. Moreover, and again we believe this to be in line with baccalaureate programs elsewhere, students are encouraged to develop a critical attitude to information and problem solving skills throughout their program of study.

The second set of objectives is covered by the inclusion of six introductory courses in IT, as well as ten advanced courses. The introductory courses include a course entitled "Introduction to IT" and a followon course "Survey of IT", two Java programming courses and courses in Discrete Mathematics and Statistics.

Each of the advanced courses belongs to one of five areas. The five areas are: IT management issues, systems development and support, knowledge management, telecommunications and network administration, and web and multi-media foundations. All students read at least three courses in the first area (IT management issues), including one in project management, enabling them to achieve objective 9, the ability to use advanced project management methods in complex systems development environments. Each student also reads one introductory course from each of the remaining four areas. Thus, they read a course entitled "Systems Analysis and Design" from the systems development and support area, "Data Management" from the knowledge management area, "Data Communications" from the telecommunications and network administration area and "Web Application Design and Development" from the Web and multimedia foundations area.

Students also choose one of the four areas as their area of specialization, and subsequently read another 3 courses in their chosen area of specialization. For example, if a student chooses to specialize in the area of knowledge management, they will read 3 courses on decision support systems, information organization and retrieval, and knowledge discovery and data mining.

Obviously, these various courses allow student to attain objective 1, the ability to identify and define the requirements that must be satisfied to solve organizations' problems or opportunities; objective 5, the ability to identify current and emerging technologies and their applicability to today's organization; and objective 6, expertise in the core technologies that support all IT based applications. Moreover, since many of the IT courses include group projects in their assessment, the courses also help students attain objective 8, the ability to work effectively in project teams to implement IT based solutions. Table 1 summarizes the advanced IT courses (course in italics are compulsory for all students majoring in IT).

This leaves the final set of objectives, namely objective 2, the ability to create IT-based solutions in one or more application areas, and objective 4, the ability to apply rational analytical technique to the development of IT-based solutions. Since this is one of the most innovative aspects of the baccalaureate program at Georgia Southern University, we discuss how we attempt to help students achieve these objectives in the next section. 


\begin{tabular}{|c|c|}
\hline Stream & Courses \\
\hline Project Management & $\begin{array}{l}\text { Project Management and Development } \\
\text { Software Acquisition, Integration and Development } \\
\text { Information Technology Issues and Management }\end{array}$ \\
\hline Systems Development and Support & $\begin{array}{l}\text { Systems Analysis and Design } \\
\qquad 3 \text { from: } \\
\text { Applications Development with Objects } \\
\text { Decision Support Systems } \\
\text { Discrete Simulation } \\
\text { Network Operating Systems }\end{array}$ \\
\hline Knowledge Management & $\begin{array}{l}\text { Data Management } \\
\text { Decision Support Systems } \\
\text { Information Organization and Retrieval } \\
\text { Knowledge Discovery and Data Mining }\end{array}$ \\
\hline $\begin{array}{l}\text { Telecommunications and Network } \\
\text { Administration }\end{array}$ & $\begin{array}{l}\text { Data Communications } \\
\text { Network Administration } \\
\text { Computer Organization/Architecture } \\
\text { Network Operating Systems }\end{array}$ \\
\hline Web and Multimedia Foundations & $\begin{array}{l}\text { Web Application Design and Development } \\
\quad 3 \text { from } \\
\text { Problems in Web Applications Implementation and Devel- } \\
\quad \text { opment } \\
\text { Web Software Tools } \\
\text { Writing for Electronic Media } \\
\text { Multimedia Presentations }\end{array}$ \\
\hline
\end{tabular}

Table 1: Advanced IT Courses

\section{Integrating Application Areas into an Information Technology Curriculum}

One of the aspects that distinguishes the IT baccalaureate program at Georgia Southern University from other baccalaureate programs in IT is its greater emphasis on application areas. This is reflected in objectives 2 and 4, which require the students to demonstrate the ability to develop IT-based solutions in one or more application areas. However, it is commonly accepted that, in order to develop IT-based solutions for a particular application area, it is crucial that one acquire an in-depth knowledge of that area. Thus, to develop IT-based solutions for the insurance industry, one needs not only IT skills, but also a good understanding of the insurance industry. In order for students to achieve the ability to develop ITbased solutions for one or more application areas, they must therefore acquire considerable knowledge of an application area. It is for this reason that each student wishing to major in IT at Georgia Southern University has to read a second discipline.

A second discipline consists of a coherent set of courses in a discipline other than Computer Science, Information Systems, or IT. Departments interested in offering a second discipline are asked to submit a rationale, describing how the second discipline relates to IT and why IT majors would benefit from tak- 
ing this specific discipline. They also submit a program of courses, which must be directly relevant to the rationale provided. Students are required to read 21 credit hours in the second discipline. It is worthwhile to compare this to the number of credit hours that students are required to read in IT, namely 48. In other words, students obtain about a third of their credits not related to their general educational requirements in the second discipline.

The list of second disciplines available to students is steadily growing. The most current version is available at http://www2.gasou.edu/coba/depts/sit and includes:

- Applied Integrated Manufacturing

- Digital Imagining Systems

- Electronic Broadcast Media

- French

- Geographical Information Systems

- German

- Imaging Information Systems

- Information Technology and the Administration of Justice

The rationale for most will be clear. For example, students with good skills in IT would benefit from the acquisition of technical writing skills as this will enable them to become technical writers, or visual communication design skills as these skills will help them design better and more visually appealing web pages, or skills that allow them to process and manipulate images. Similarly, the communications and broadcasting industry is fully integrating IT into its production and distribution processes, and IT students with a good understanding of broadcast media will therefore be able to create interesting novel applications for this industry. Finally, IT majors with in-depth knowledge of supply chain management would be of great value to a great number of retail organizations while those with a good understanding of manufacturing would be a great asset to most manufacturing firms.

The rationale behind the second disciplines of French, German and Spanish is also not hard to understand. Given increasing globalization, both in commerce and culture, and the presence of large groups of French and Spanish speakers to the north and the south of the United States, and the important trading links between the United States and Germany, an IT major who is proficient in French, German or Spanish will be of great value to many organizations with international contacts, such as manufacturing firms that export to Canada, Latin America or Europe.

Perhaps the only two disciplines that may appear unrelated are IT and the Administration of Justice and Technology and Political Analysis. The rationale for the former is that the role of IT within the administration of justice system is evolving and that there is likely to be a need for new IT applications within this sector. The events of September 11, 2001 are only likely to accelerate this trend. IT majors with an understanding of the justice system will be able to develop these applications. The rationale for the second discipline in Technology and Political Analysis is similar. IT is playing an increasingly important role in both legislative and the electoral processes, as testified by the introduction of electronic voting machines in a number of states, and students with an exposure to these aspects of political science are therefore well-placed to take advantage of job openings that the increasing reliance on IT in this sector will generate.

In a sense, the second disciplines IT and the Administration of Justice and Technology and Political Analysis are perhaps the most interesting. After all, they demonstrate that, with a good rationale, almost any discipline can become of interest to IT majors. A little reflection shows that this is perhaps not as surprising as it may seem at first sight. One of the most prominent aspects of IT is its ubiquity and the 
fact that it has influenced almost all forms of human activity. In order to prepare IT majors to take advantage of the myriad of opportunities that this opens up, one needs to include an exposure to these new application areas in any IT curriculum and we believe that our second disciplines do so.

However, merely making second disciplines available and insisting that IT majors take one is clearly not enough. Students also need to be made aware of the range of second disciplines that are open to them. We therefore invite representatives from second disciplines to briefly talk to our students as part of the Survey of IT course. This course is the second course in IT that majors take, the first being Introduction to IT. While both have a practical component in which students are taught tools for building web-based applications (HTML and JavaScript), the primary emphasis in Introduction to IT is on IT as an academic discipline and the similarities and differences between it and its parent disciplines Computer Engineering, Computer Science and Information Systems. Students also receive a first exposure to software engineering techniques in general and object-oriented design techniques in particular. The primary focus of Survey of IT is on the use of IT, and we feel that this is the appropriate place to expose students to the second disciplines that are available to them. The first and purely practical reason is that the course is early enough in the students' overall program of study to give them to opportunity to reflect on which application area they would like to concentrate on. The second, and more pedagogical, reason is that the range of second disciplines available to students also provides a good illustration of the allpervasiveness of IT. It therefore helps convince students that IT is indeed a field that opens many opportunities to them, some of which will come as a -one hopes- pleasant surprise to them. For more details on this course, the reader is referred to Reichgelt, Price and Zhang (2002).

Finally, in common with many other baccalaureate programs in IT, IT majors at Georgia Southern University are also required to do a not-for-credit 180-clock hour internship. Students are strongly encouraged to do an internship related to their second discipline. The hope is that, having acquired an in-depth knowledge of IT in the IT courses and of a particular application area in their second discipline, the internship will enable them to develop hands-on experience in an application area of interest to them.

\section{Conclusion and Future Work}

Many national and regional governments have made the provision of IT Services an important element in their economic development strategies. However, at the same time, there is a severe shortage of skilled IT professionals, and obviously this shortage has to be addressed by educational institutions. Georgia Southern University is trying to help alleviate the shortage of IT personnel through its baccalaureate program in IT. The curriculum was formulated after extensive research of existing IT baccalaureate programs and after extensive consultations with leading employers of IT graduates. It was the latter's complaint that they had great difficulty recruiting applicants for IT related entry-level positions with both a solid grounding in technical matters and an in-depth knowledge in the area of particular interest to the company that led to the inclusion of so-called second disciplines in the baccalaureate program offered at Georgia Southern University. Second disciplines give students an in-depth exposure to a potential application area of IT. While, as far as we know, Georgia Southern University's curriculum is unique in insisting that all IT majors get a good grounding in an application area, we believe that this aspect of our curriculum is one that easily translates to other institutions, and, moreover, will lead to graduates that are more likely to meet the demands of organizations with a large IT workforce.

\section{References}

Georgia Southern University (2000). School of Information Technology Task Force Report: Academic and Facility Plan. Statesboro, GA.

ITAA (2002). Bouncing Back: Jobs, Skills and the Continuing Demand for IT Workers. Arlington, VA.

Reichgelt, H., Price, B. \& Zhang, A. (2002). The Inclusion of Application Areas in IT curricula. Proceedings 2002 Conference on Information Technology Curriculum, Rochester, NY. 
U.S. Department of Commerce, Secretariat on Electronic Commerce (1998). The Emerging Digital Economy. U.S. Department of Commerce, Washington, D.C., April 1998.
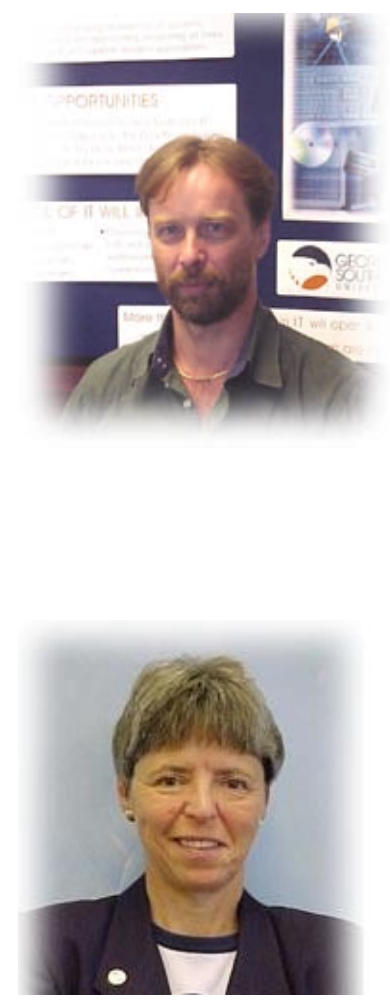

\section{Biographies}

Han Reichgelt is Associate Professor of Information Technology at Georgia Southern University in Statesboro, Georgia. He holds first degrees in philosophy and psychology from the University of Nijmegen in the Netherlands and a $\mathrm{PhD}$ in Cognitive Science from the University of Edinburgh, Scotland. $\mathrm{He}$ is the author of a textbook in knowledge representation and over 20 journal articles and some 50 refereed papers in conference proceedings. Prior to joining Georgia Southern University he was Professor of Computer Science at the University of the West Indies, Mona, Jamaica. His research interests include data mining, electronic commerce, expert systems, IT and computer science education, as well as Information Technology and economic development.

Barbara Price received her Bachelor of Science in Mathematics from Grove City College in 1969. In 1971, she earned her Master of Science in Statistics from Virginia Polytechnic Institute and State University. Dr. Price received a Doctor of Philosophy in 1973. She has worked in various academic positions throughout the southeast, served as an exchange professor at Deakin University in Australia, taught at Winthrop University, and served as both professor and department chair for the Department of Information Systems and Logistics at Georgia Southern. Most recently, Dr. Price was appointed founding director for the School of Information Technology. She serves in several professional societies including the Decision Sciences Institute (At-large Vice President), ACM (CM Alternate Representative Director to the CSAB Board), INFORMS, and AIS. She has over fifty publications in various professional journals and proceedings.

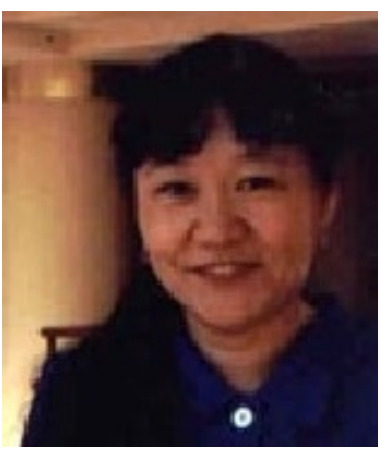

Aimao Zhang received her Bachelor of Science from Indiana University of Pennsylvania in 1990. She earned her Masters of Business Administration in 1991 from Indiana University of Pennsylvania. She was awarded a Doctor of Philosophy in 2001 from Southern Illinois University at Carbondale with a major in Management Information Systems and a minor in Production/Operations management. Earlier, she worked as a project coordinator for The Ministry of Metallurgical Industry in Beijing, China. She has broad interests in teaching and research and has taught and is teaching courses in information technology. Dr. Zhang's publications include book chapters, papers in refereed journals, and national conferences. 


\section{Appendix A -- Companies Providing Information}

Companies visited:

- BellSouth Corp.

- The Coca-Cola Company

- Environmental Systems Research Institute (ESRI)

- The Home Depot Inc.

- Georgia-Pacific Corp.

- Southern Company Inc.

Companies that provided information through questionnaires:

- Abaco

- The Coca-Cola Company

- Equifax Inc.

- esavio corp.

- ESRI

- Georgia-Pacific Corp.

- The Home Depot Inc.

- IXL of Atlanta

- Southern Company Inc. 